\title{
UTILIZING AUDIO VISUAL AIDS TO IMPROVE ENGLISH SPEAKING SKILL FOR THE EIGHT GRADE STUDENTS OF SMP NEGERI 3 BANAWA
}

\author{
Irmawati \\ IAIN Palu \\ Irmawaty.jr@gmail.com
}

\section{INTRODUCTION}

English has four skills, namely: listening, speaking, writing, and reading. It plays very important role because as International language (Marzuki, 2017a). Although all four skills are equally important, it is easy to understand that people say that those who know English are referred to as "speakers" of English (Picollo, 2010). Therefore an English teacher must be able to motivate students to learn English, especially speaking skills. That the ability to communicate in second language clearly and efficiently contributes to the success of the learner in school and success later in every phase of life (Brown, 2001).

Speaking is a process of oral communication that is used for ideas or thoughts, so that they can interact with other people (Marzuki, 2017b). Speaking is an interactive process in building meaning that involves production and acceptance and processing of information (Brown, 2001). Most students have difficulty in speaking English because of the factors that first; they are shy to speak if their teacher asks them to speak. They do not know how to use appropriate grammar, so it makes them afraid of making mistakes. Second, they do not have enough opportunities to practice English because they have limited time only during English lesson themselves. Speaking is also considered as the most difficult and challenging skill to be mastered (Brown, 2001). Implemented in the 2013 curriculum, that the ultimate goal of teaching English in Junior High School is to develop students' communicative English language in the form of oral and written language, namely: listening, speaking, reading and writing.

Based on observation in SMP Negeri 3 Banawa, the researcher found that this school has problems in learning English, especially in learning to speak. Some problems arise from students and teachers. These problems are from the teacher's side: (1) the teacher provides material based on the book. (2) teachers use traditional methods, for example asking students to read text in books or student exercise books and practice in front of the class. These problems not only come from the teacher but also from the student side: (1) passive students in the class, during the teaching and learning process. (2) students become noisy and talk to each other when the teacher explains the material (3) students find it difficult to capture the teacher's explanation, because they do not understand. (4) students do not have the motivation to learn about English, especially in speaking, they think that speaking is difficult to practice and they are not confident enough to speak.

Regarding the problem above, researcher used audio visual aids that can be used to improve students' speaking skill. Audio Visual aids is a suitable medium that can be used to overcome existing problems, because utilize audio visual can make learning interesting and students will feel interested in talking and can express their ideas what they see and listen 
(Madhuri, 2013). It is a well-known fact that audio-visual materials are a great help in stimulating and facilitating the learning of a foreign language (Çakir, 2006). In other words, the use of audio visual has a positive contribution to language learning as long as they are used at the proper time, in the right place. Because multimedia consists of tools that appeal to the human senses such as visual and audio tools used in foreign language teaching increasing the number of emotional inputs, the level and quality of one's language skills also increases. The quality and the quantity of the output such as writing and speaking skills, which are of utmost importance for language learning, becomes higher. From this point of view, video and pictures, which are audio tools, are important resources for students while developing lingual skills.

The audio-visual aids have an important role in improving the speaking skills of the students, because there are so many advantages we can take by using audio-visual aids. Practically the use of audio-visual aids is one of the appropriate techniques to improve students' speaking skills. Through audio-visual aids, the students are more enthusiastic. Students enjoyed the process of teaching and learning more. Teaching speaking using audio-visual aids gives a big chance to the students to speak. It also provides an opportunity to develop accuracy, fluency and keeps the learners highly motivated. The facilities already provided by the school, it is regrettable if the teacher did not use them.

Based on the problems and the propose solution above, the researcher interested in conducting a classroom action research entitled "Utilizing Audio Visual Aids to Improve Speaking English Skill for the Eight Grade Students of SMP Negeri 3 Banawa"

\section{Problem Statement}

Based on the background of the study above, the researcher investigated whether audio visual aids could improve speaking skill in English for the second grade students' of SMP Negeri 3 Banawa, the problem statement of this research is formulated as follows :

How can the students' speaking skill be improved through the utilization of Audio Visual Aids?

\section{Objectives of the Research}

The objective of the research is to know whether students' speaking skill can be improved through Audio Visual Aids.

\section{RESEARCH METHOD}

\section{Research Design}

In this research, the researcher used classroom action research method. Classroom action research is a research that is done by a teacher, collaborate with the researcher (or a teacher, itself as a researcher) in a class or in a school that the teacher teaches to improve process and practice learning (Arikunto, 2010; Marzuki, 2016). Moreover, classroom action research is developed through self-reflective spiral, a spiral of cycles of planning, acting, observing, reflecting, the re-planning (Burns, 1999).

This method consist of four steps; planning, action, observation, and reflection. The implementation of classroom action research included four steps as follows:

1. Planning 
In this phase, the researcher developed action research after identifying problems. It includes the planning for lesson plan, teaching method or technique, and teaching materials.

2. Action

Action is the realization which is plan before. The researcher started to act what has been plan such as using technique and material.

3. Observation

In this phase, the researcher was assisted by the collaborator about the technique of teaching in the class in the material delivery and teaching learning process, about the student's interaction, opinions, performance, and other activities written down in a field note.

4. Reflection

In this phase, the researcher reflected on, evaluate and describe the effects of the action. All the notes and field note from the researcher and the collaborator were collected and reflected. It will be used for better understanding or knowing improvement on the next planning or action.

This following figure can describe the research method there are four steps in this model of action research namely: planning, implementing the action, observation and reflecting.

The action research was conducted in some cycles; depend on the aim of the research study. The process was conducted as the cycle(s) below:

\section{Research Subject}

The subject of this research was conducted in the eighth grade students of SMP Negeri 3 Banawa in 2019/2020 academic year. Exactly, it was at the second semester of the year. There are 28 students in class VIII A as respondents of the research. There are some reasons why the subject was chosen. Such as; the students of this class has lower ability in English lesson, especially in speaking English, the class has a enough quantity of the students to do research.

\section{Technique of Collecting Data}

The data collected were qualitative and were supported by quantitative data. By giving the description of the situation in the teaching and learning process, the qualitative data were gained. Meanwhile, from the score of the students' performances in the end of the cycles, the quantitative data was also taken. It was conducted to find out the improvement of the speaking ability of the students. In gaining the data, the researcher collected the data by using some data collection techniques as follows:

1. Observation

In this technique, the data was taken from the notes about everything happen during teaching learning process which were about the teacher's treatment to the students, which method the teacher used and how the process work. The observation also was about students' responses and participation in teaching learning process. This method 
is also as a barometer to do previous data collecting. By direct observing, there are possibilities to take some notes, behavior, development, and so on, which happens any time (Burns, 1999).

2. Interview

The way of collecting data of pre-action was used also interview guidelines. It will be the second technique to get more information in collecting data. There two kinds of interview which were used. They are: unstructured interview and structured interview (Arikunto, 2010; Marzuki, 2019a). The interview conducted to both English teacher and some students who the participants of teaching learning process. The interview was be about the English teaching learning process at SMP Negeri 3 Banawa which was conducted before and after implementing Audio Visual Aids in teaching speaking. Then, the result of interview was taking as guidelines to complete the data needed.

3. Questionnaire

In this collecting data technique, gaining the data was conducted twice, pre-action and after implementing CAR. It will use structure questionnaire which contained the questions and alternative answers to them. In this technique, the students are supposed to choose one of the alternative answers according to their personal estimation of each question. After conducting this phase, it result a percentage of students' response. It is aim to support other data to get a valid research result.

4. Documentation

In action research, the use of photograph is underexplored (Burns, 1999). Photographic data give a way of richly illuminating numerous aspects of the classroom quickly and relatively in expensively and providing new angles on the context being researched. Photographs are a way of enhancing classroom analysis and providing visual stimuli which can be integrated into reporting and presenting the research to others, used with other qualitative techniques.

Recording is done through the video tape and/or audio tape to monitor and to evaluate the actions. Meanwhile, the quantitative data were gained through pretest and post-test to measure the improvement of students' speaking skills.

5. Test

The test was the last technique to know about the students' improvement of understanding speaking by utilizing audio visual aids (Marzuki, 2018). This technique will used to know the students' achievement in learning speaking skill utilize audio visual aids. It may be as the main technique in collecting data. So, this technique was told more how this technique work to prove that audio visual aids could improve the students' understanding of speaking skill.

The results of tests were providing by some tables to make it more efficient and communicative enough (Sugiyono, 2005). To see the students' of their speaking skills, the researcher used tests as the instrument (Marzuki, 2017b). The test was conducted 
twice, in the last meeting of each cycle. The researcher asked them to do a conversation in a pair, in the form of role play for testing the students.

\section{The Procedure of Classroom Action Research}

This procedure of this research is planning, action and observation, and reflecting. The procedures of Classroom Action Research in each cycle are:

\section{a. Planning}

To improve the students' speaking skills, the researcher worked together with another researcher, and the English teacher. The aim of the action is to improve the students' speaking skills using audio-visual aids to support the communicative teaching. The action plans as follows:

1. using audio-visual aids in teaching speaking

2. reviewing the materials and media

3. testing the students' speaking skills.

b. Action and Observation

Some action plans are implemented in the classroom in two cycles; depend on the research study itself. Each cycle was about two meetings. Besides implementing some action plans, the researcher and the collaborator observe and record the teaching and learning process, and was interview with some students of grade VIII A after the action done. All the members involve in the research discussion based on the actions analysis. The result of the discussion was important to serve as an evaluation for the implementation of the action plans to improve the next actions.

c. Reflecting

Reflecting is the activity of evaluating critically the progress of the students. Analyzing the action in order to remember what happen that has been written in observation. In this step, the researcher can observe whether the action activity result any improvement.

\section{A. Criteria of Success}

The criteria of success in this action research are as follows:

1. For seventh and eighth class the average of the obtained scores is 70.00 (this is the minimum of mastery standard at SMP Negeri 3 Banawa).

2. The students' interest in learning by utilizing audio visual aids. It means the students are interest to improve their speaking skill of English by utilizing audio visual aids. These data are obtained from the observation sheet, field-note and the questionnaire (adapted from Marzuki, 2017a; Marzuki, 2019b).

\section{Discussions}

This study aims to describe how the utilization audio visual aids can improve the speaking skills of class VIII A SMP Negeri 3 Banawa. Referring to the purpose of the study, the findings show that the use of audio visual aids can improve students' speaking skills in aspects of 
comprehension and fluency. The effects of using audio-visual are almost twice that of using audio or visual media only (Sugeng, B. 2010).

Utilization of audio-visual aids (video and slide) and supporting actions include applying daily conversation and descriptive text, using English in class during the teaching and learning process, providing feedback to students, giving handouts and giving prizes successfully increasing students' speaking abilities of VIII A grade students Negeri 3 Banawa. The findings can be concluded from observations and interviews with English teachers and students during the study.

The result in cycle the average 57.78, were able to increase their score to 72.67 in cycle II. In conclusion, the use of audio visual aids has proven effective for improving students' speaking skill. Ahmad states that in audio-visual aids, both hearing (ears) and vision (eyes) are involved (Ahmad, 2013). Such assistance includes television programs, video films, motion pictures, synchronized audio-slide projectors, computers and computer-aided instructions and so on. Cartoon films are also useful media for developing and sculpting students' skills. Based on interviews, the students said that they had some improvement in their speaking skills by watching videos. They know the correct pronunciation and can use it in their dialogue. Even their fluency is also improved because they gain confidence after they know the correct pronunciation of the video.

\section{CONCLUSION AND SUGGESTIONS}

\section{A. Conclusion}

After implementing the two cycles, the researcher found some effective ways to improve the speaking skills of the eight grade students at SMP Negeri 3 Banawa academic year of 2018/2019 by utilizing audio-visual aids.

1. The use of audio-visual aids can attract students' attention and motivation in learning English, especially speaking which can make students build their confidence.

2. Students can get a better understanding of the material given, because audio visual gives them clear examples of the real context in life. Students can interpret meaning only by watching videos.

3. Activities such as playing games and playing dialogue, more opportunities to practice their speaking skills. They can interact with all their friends because the task requires them to do it. Some students mix in English and Indonesian in answering teacher questions or instructions. It's good since a long time ago; they even use Language in English classes. This shows that students' willingness to try to use English when they speak increases. Therefore, the teaching and learning process becomes more interactive and communicative. They also like to do this activity in front of the class. Students who only got 57.78 in cycle I were able to increase their score to 72.67 in cycle II. This shows that they make aspects of speaking skills such as comprehensibility and fluency.

\section{B. Suggestions}

1. To Students 
The process of teaching and learning English can be effective if each participant involved makes a positive contribution. Thus, students as the subject of the teaching and learning process must actively participate in activities during class. They need to continue to practice if they want to speak fluently

2. To English Teachers

English teachers must consider students' needs and interests before designing speaking material. The speaking process and teaching and learning process is very important. This is a monotonous learning process. Audio-visual aids in the teaching and learning process because audio visual aids help teachers deliver material easily in interesting ways.

3. To Other Researchers

This is a limited time study in implementing actions. This makes researchers can only use one type of audio-visual aid, namely video. Other researchers who are interested in implementing actions over a longer period are more likely to be seen. This is also authentic audio visual aids.

\section{REFERENCES}

Ahmad, T. Audio-Visual Aids in .http://dailykashmirimages.com . Retrieved on December 21st 2018.

Brown, H.D. Teaching by Principle: An Interactive Approach to Language Pedagogy. New York: Longman, 2001.

Burns, A. Collaborative Action Research for English Language Teachers, 1999.

Çakir, D. I. The use of video as an audio-visual material in foreign language teaching classroom. The Turkish Online Journal of Educational Technology, 5(4), 67-72. Retrieved from http://www.tojet.net/articles/v5i4/549.pdf, 2018.

Madhuri, J. N. Use of Audio Visual Aids in Teaching and Speaking. Research Journal of english Language and Literature (RJELAL). Retrieved on December 20th 2013, 2018.

Marzuki, A. G. (2017). Applying mind mapping technique in improving english vocabulary mastery in an efl classroom. Paedagogia: Jurnal Pendidikan, 6(2), 276-293.

Marzuki, A. G. (2019). The Implementation of SQ3R Method to Develop Students' Reading Skill on Islamic Texts in EFL Class in Indonesia. Register Journal, 12(1), 49-61.

Marzuki, A. G. (2019). Utilizing Recorded English Dialogues in Teaching English Word Stress to Islamic Higher Education Students in Indonesia. Jurnal Pendidikan Islam, 5(1), 43-54.

Marzuki, A. G., Alim, N., \& Wekke, I. S. (2018). Improving the reading comprehension through cognitive reading strategies in language class of coastal area in indonesia. In IOP Conference Series: Earth and Environmental Science (Vol. 156, No. 1, p. 012050). IOP Publishing.

Marzuki, A.G. (2016). Utilizing cooperative learning in islamic college students' classroom, IJEE (Indonesian Journal of English Education), Vo. 3 No. 2, p. 123-139.

Marzuki, A.G. (2017). Developing speaking skill through oral report in an efl class in indonesia, Al-Ta'lim Journal, Vo. 24 No. 3, p. 243-254.

Picollo, L. Teaching Speaking to English Second Language Students. Retrieved from http://suite101.com/ article on 1 January 2013, 2018. 
Sugeng, B. Instructional Technology: Planning Strategies for Language Education. Yogyakarta: Unpublished teaching and learning modul, 2010.

Sugiyono, Statistika untuk Penelitian, (Bandung: Alfabeta, 2005), p. 22.

Suharismi Arikunto, Prosedur Penelitian, (Jakarta: Rineka Cipta, 2010) 